University of Nebraska - Lincoln

DigitalCommons@University of Nebraska - Lincoln

US Army Research

U.S. Department of Defense

2012

\title{
Controlled expedient disposal of excess gun propellant
}

M.R. Walsh

U.S. Army Corps of Engineers, Michael.Walsh@usace.army.mil

S. Thiboutot

Defence Research and Development Canada

M.E. Walsh

U.S. Army Corps of Engineers

G. Ampleman

Defence Research and Development Canada

Follow this and additional works at: https://digitalcommons.unl.edu/usarmyresearch

Walsh, M.R.; Thiboutot, S.; Walsh, M.E.; and Ampleman, G., "Controlled expedient disposal of excess gun propellant" (2012). US Army Research. 232.

https://digitalcommons.unl.edu/usarmyresearch/232

This Article is brought to you for free and open access by the U.S. Department of Defense at DigitalCommons@University of Nebraska - Lincoln. It has been accepted for inclusion in US Army Research by an authorized administrator of DigitalCommons@University of Nebraska - Lincoln. 


\title{
Controlled expedient disposal of excess gun propellant
}

\author{
M.R. Walsh ${ }^{\mathrm{a}, *}$, S. Thiboutot ${ }^{\mathrm{b}}$, M.E. Walsh $^{\mathrm{a}}$, G. Ampleman ${ }^{\mathrm{b}}$ \\ a U.S. Army Corps of Engineers, Cold Regions Research and Engineering Laboratory, 72 Lyme Road, Hanover, NH 03755-1290 USA \\ b Defence Research and Development Canada, DRDC-Valcartier, 2459, Pie XI Blvd. North, Québec, QC G3J 1X5, Canada
}

\section{A R T I C L E I N F O}

\section{Article history:}

Received 16 December 2011

Received in revised form 5 March 2012

Accepted 21 March 2012

Available online 29 March 2012

\section{Keywords:}

Propellants

Burn pan

Lead

Disposal

Residues

\begin{abstract}
A B S T R A C T
The expedient field disposal of excess gun propellants on the ground is an integral part of live-fire training in many countries. However, burning excess propellant in the field will leave significant quantities of energetic residues and heavy metals in the environment. Compounds such as dinitrotoluene and nitroglycerin and metals such as lead will leach into the soil column, eventually migrating to groundwater. Contamination of the environment will lead to high remediation costs and the possible loss of the training facility. After investigating the contamination at several propellant disposal sites, a portable propellant burn pan was developed and tested. The pan was transported to training sites where excess propellant was loaded and burned in a controlled manner. Up to $120 \mathrm{~kg}$ of excess single-base propellant charges have been burned during two series of tests at a consumption rate of greater than $99.9 \%$. Less than $0.03 \%$ of the energetic material was recovered outside the burn pan. Recovered lead is largely contained within the pan. The turnover rate for burns is $15 \mathrm{~min}$. The residues can be collected following cool-down for proper disposal.
\end{abstract}

Published by Elsevier B.V.

\section{Introduction}

Live-fire training is an essential element for maintaining combat efficiency for military personnel. Field training with artillery, which encompasses mortars and howitzers, requires the use of munitions that are issued with a full complement of propelling charges. These charges enable the firing of the projectile to maximum range. Because of the objectives of a particular training mission, restrictions placed on ranges, and stress on the weapon systems from the use of the maximum number of charges, most training exercises do not require the use of all the issued charges. The excess charges can be returned to the ammunition supply point (ASP) for reissue, returned to the ASP for centralized disposal, or disposed of at the firing point by the troops as part of their training. Because most current propelling charges are not reusable and because there are inherent risks in handling and transporting open propellant charges, most excess propellant is destroyed by burning in the field, generally on the ground near the firing point.

In the U.S. and many other countries, the field disposal of excess propellants is considered an integral part of combat training. It is what happens in actual combat situations, so the troops need to be trained on the proper disposal procedure in the field. Research by the U.S. Army Cold Regions Research and Engineering Laboratory (CRREL) has shown that expedient field disposal of excess

\footnotetext{
* Corresponding author. Tel.: +1 603646 4363; fax: +1 6036464720 .

E-mail address: Michael.Walsh@usace.army.mil (M.R. Walsh).
}

propelling charges will result in inefficiencies related to unconfined burning and climatic conditions, leading to unreacted residues rates as high as in the $20 \%$ range [ $1-3$ ]. These residues may contain nitroglycerin (NG), dinitrotoluenes (DNTs), and other compounds that pose a health risk in the environment. In addition to energetic residues, heavy metals are present in some charges. Lead, used as a decoppering agent in howitzer charges, will be disbursed during the burning of the charges, resulting in an immediate inhalation risk as well as cumulative soil deposition that may lead to groundwater contamination [4]. Heavy metal and energetic compound contamination of the underlying aquifer will lead to range restrictions or closures [5].

Burn pans currently exist at ASPs and in training range complexes. The concept of a burn pan is not complex, as in its most basic form it is an open-topped steel box. However, most burn pans are not efficient and procedures are not always followed. Improper burning of propellants leads to inefficiencies, such as ejection of propellant grains, and may lead to detonation [6]. Following the burn tests in Alaska [2], CRREL and Defence Research and Development Canada-Valcartier (DRDC) embarked on a two-pronged investigation into developing more efficient burn pans, DRDC for a centralized burn facility at a post ASP and CRREL for field use with training units [7]. The hypotheses tested here are that a correctly designed burn pan will enable the safe, efficient burning of excess propellants, will capture most of the unburned residues including the heavy metals within the structure, and will enable training troops to conduct field disposal operations at firing points without adverse environmental impacts while still training as they will 
fight. This paper examines the CRREL portable burn pan: its design, fielding, performance, and current status.

\section{Background}

Prior to initiation of the burn pan design process, tests were conducted with limited numbers of propellant charges to determine the constituents of concern and the amount of unburned residues that will result under different burn conditions [1,2]. Deposition rates for these small-mass $(<1 \mathrm{~kg})$ double-base mortar propellant burns ranged up to $18 \%$ of the original mass of the analyte (NG). The most efficient burn occurred in a $34-\mathrm{cm}$ diameter by $11-\mathrm{cm}$ deep bowl, which contained the charges, separating them from direct contact with the environment. Over $70 \%$ of the residues were recovered outside the bowl, indicating that a burn pan design of a similar configuration would not be ideal. Burning of single-base howitzer propellants in near-ideal conditions resulted in residues rates of around $1 \%$ of the original mass of the analyte (DNT). A third burn trial was conducted with propellant charges using a large pot (20-cm ø $\times 60$-cm tall). The ejection of propellant charges occurred, mostly due to igniting the $15-\mathrm{cm}$ deep pile of charges from below. Unburned NG in the residues was estimated to be $0.29 \%$ of the original NG mass of the propellant bags burned. Most (64\%) of the residues were recovered from the surrounding snow matrix [7].

\section{Experimental}

To determine if surface contamination was occurring at locations with structures designed for propellant disposal, we characterized the soil surrounding a well-used burn pan located on a range complex in the U.S. (Fig. 1a) The site was characterized three times: in July 2003, September 2008, and July 2009. Replicate multiincrement soil samples were collected from various-sized sampling units that encircled the burn pan to determine soil concentrations as a function of distance from the pan. Samples were collected with stainless steel scoops (2003) and a 3-cm diameter coring tool to a depth of $2.5 \mathrm{~cm}$ (2008 and 2009). The bottom of the burn pan was corroded through, allowing accumulated precipitation to percolate through the residue onto the soil. Propellant grains were observed and removed from the soil surface prior to sampling. These conditions indicated that the current box design was not sufficiently containing the residues from the burn as well as allowing propellant grains to be ejected. Samples were processed and analyzed for NG and DNT in accordance with EPA Method 8330B [8]. Metals analyses were done in accordance with EPA Methods 6020A and 3051A $[9,10]$.

Using lessons learned from these small-scale tests and the site characterization, a full-scale prototype portable burn pan was designed. Built entirely of stainless steel, the burn pan was an adaptation of the standard open box design with the addition of a false bottom, higher sides, and screening over the top (Fig. 1b). The false bottom was included to prevent warping and corrosion of the lower part of the structure (pan) from the heat of combustion while the open mesh screening on the removable top part of the structure (bonnet) was designed to break up any debris that may be ejected from the unit. A series of burns was scheduled in conjunction with test burns of the Canadian stationary burn pan at DRDC's Munitions Experimental Test Centre in Valcartier, Québec, in late March 2010.

Burn tests were conducted over two days, 30-31 March 2010. Three tests were conducted on 30 March and one the morning of 31 March. At the time, the ground was covered with a thin layer of snow and temperatures hovered around $3{ }^{\circ} \mathrm{C}$ under partly cloudy, windless skies. Temperature sensors were mounted to the center of the screen on top of the bonnet, attached with screws to the outside of the center of one of the sides and the bottom of the main pan, and
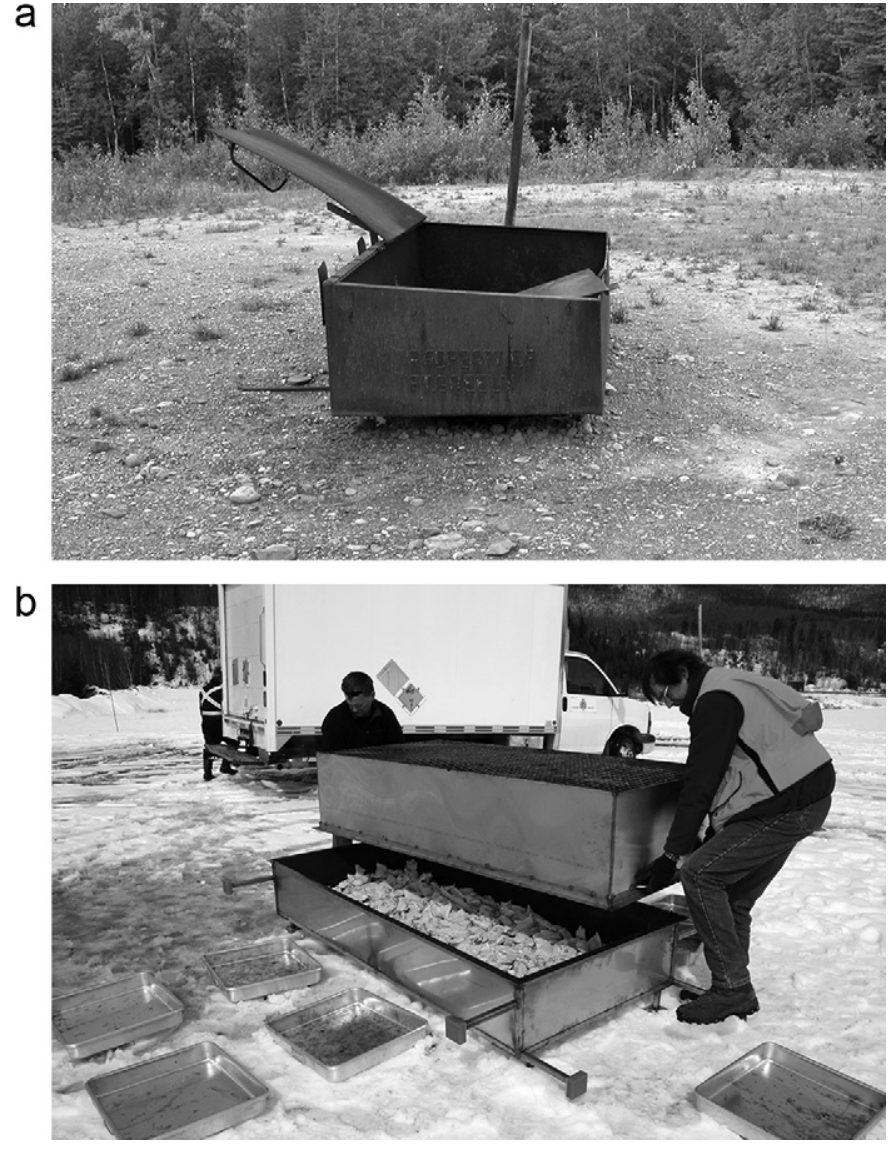

Fig. 1. Burn pans. (a) Existing fixed burn pan on a range complex. (b) Preparing portable burn pan for disposal operation.

on a pole $6 \mathrm{~m}$ from the side of the pan and at a height of $2 \mathrm{~m}$. Ten trays (Area $=0.28 \mathrm{~m}^{2}$ each) were arranged around the burn pan to collect any ejected residues and debris. For each test, the propellant charges were loaded and distributed evenly over the false bottom of the pan and initiated. Following cool-down, the charges for the next test were loaded, distributed, and ignited. At the end of the first day, the sampling trays were collected by DRDC for energetics and lead residues processing and analysis.

For test 1,130 sets $(106 \mathrm{~kg}$ ) of 105-mm howitzer M67 propellant bags, charges $5-7$, were burned (Table 1 ). For test 2, 125 sets $(120 \mathrm{~kg}$ ) of charges $4-7$ were burned. For both tests, a $13-\mathrm{g}$ piece of lead foil was contained in the charge $5 \mathrm{bag}$, giving an estimated total of $3.3 \mathrm{~kg}$ of lead $(\mathrm{Pb})$ for the 255 sets of charges. For test 3 , a $50-\mathrm{kg}$ mixture of rocket and CA-06C10-01 mortar propellants was loaded. Most but not all the rocket propellant was removed, as the test coordinators did not know its composition. For test 4, 40 M3A1 bags ( $112 \mathrm{~kg}$ ) of $155-\mathrm{mm}$ howitzer propellant were loaded, maximizing the use of the pan area. The M3A1 propellant charges each contained $113 \mathrm{~g}$ of potassium nitrate $\left(\mathrm{KNO}_{3}\right)$ flash suppressor. The propellant in the M67 and M3A1 charges was M1 single-base propellant consisting of $10 \pm 2 \%$ DNT.

Following completion of all the burns, the ash in the pan was returned to CRREL where it was weighed and stored in glass jars at $4{ }^{\circ} \mathrm{C}$ until processing. The material was separated into three fractions using sieves: $<2 \mathrm{~mm}, 2-12.7 \mathrm{~mm}$, and $>12.7 \mathrm{~mm}$. The fractions were then placed in lab-grade clean polyethylene bags, with $<500 \mathrm{~g} /$ bag (the capacity of the grinder is $500 \mathrm{~g}$ ). Cloth and steel debris were removed from the samples to facilitate grinding. The grinder used was a LabTech Essa LM-2 puck mill with a B800 hardened steel bowl (<200 ppm Pb). Each bagged sample was ground 
Table 1

Portable burn pan tests at DRDC.

\begin{tabular}{|c|c|c|c|c|c|}
\hline Date/time & Test & Propellant & Total mass (kg) & Mass of DNT $(\mathrm{kg})$ & Mass of lead $(\mathrm{kg})^{\mathrm{b}}$ \\
\hline \multicolumn{6}{|c|}{30 March 2010} \\
\hline $1020 \mathrm{~h}$ & 1 & M1 & 106 & 10.6 & 1.7 \\
\hline $1115 \mathrm{~h}$ & 2 & M1 & 120 & 12.0 & 1.6 \\
\hline $1305 \mathrm{~h}$ & 3 & $\mathrm{M} 1+$ Rocket $^{\mathrm{a}}$ & 50 & 5.0 & - \\
\hline \multicolumn{6}{|c|}{31 March 2010} \\
\hline $0920 \mathrm{~h}$ & 4 & M1 & 112 & 11.2 & - \\
\hline Totals & & & 388 & 38.8 & 3.3 \\
\hline
\end{tabular}

a Most of the rocket propellant was removed prior to the test.

b Estimate based on verbal information.

according to fraction size: $<2 \mathrm{~mm}$ (ground for $30 \mathrm{~s}$ each), $2-12.7 \mathrm{~mm}$ (ground for $30 \mathrm{~s}$ ), and $>12.7 \mathrm{~mm}$ (two grinds of $90 \mathrm{~s}$ with a $>3-\mathrm{min}$ cool down between grinds). The ground ash for each size fraction was combined into a single sample representing that size fraction. A Niton XRF $700^{\circledR}$ series hand-held multi-element spectrum analyzer with a ${ }^{109} \mathrm{Cd}$ source (2 DEC 09) was used to do an initial metals characterization of each of the fraction samples. Nine readings were taken in a grid pattern over the flattened out bag containing the sample and one additional reading was obtained from a random location.

Each ground size fraction sample was then spread out over a 30$\mathrm{cm} \times 30-\mathrm{cm}$ area. Three $10-\mathrm{g}$ multi-increment subsamples $(n>40)$ were built from each sample for energetics analyses. Subsamples were then obtained for metals analysis. From each size fraction, a $100-\mathrm{g}$ batch sample consisting of a minimum of 100 increments was collected in a $120-\mathrm{ml}$ jar. The jars were shipped to a commercial lab (APPL, Fresno, CA) for final subsampling and analysis. At the lab, seven 2-g subsamples from each batch were collected using multi-increment sampling following EPA Method 8330B [8]. The subsamples were then digested in concentrated nitric acid using EPA Method 3051A and analyzed for metals on an Agilent 7500CX ICP-MS using EPA Method 6020 for metals [9,10]. The primary metal of interest was $\mathrm{Pb}$, but $\mathrm{K}$ was also of interest because of its presence in the M3A1 charges in high quantities. Samples were run at several dilutions because of the very high concentrations of these metals. Spikes and blanks were run for quality control purposes.

Designs of the two systems were discussed by CRREL and DRDC following the field test in Valcartier. The Canadian effort was well ahead of the U.S. effort, so the U.S. design was modified to incorporate some of the more successful Canadian design features. Primary among these were the changeover of the main pan from stainless to aluminum and the incorporation of perforated stainless panels on the sides and ends of the bonnet. This lowered the weight of the total structure from $225 \mathrm{~kg}$ to $127 \mathrm{~kg}$. The redesigned pan was transported to Fort Richardson, AK, where it was tested with $65 \mathrm{~kg}$ of M1 single-base artillery propellant following a training exercise by a 105-mm howitzer unit in March 2011 (Fig. 2). Multi-increment (MI) snow samples were taken in triplicate from two areas surrounding the burn pan to determine the deposition of energetics from the burn, one extending $0-3-\mathrm{m}$, encompassing all the visible residues, and one extending 3-6-m, to determine if the residues plume extended beyond the visible residues on the snow $[11,12]$. The samples were processed in the field lab on Fort Richardson and shipped to CRREL for final processing and analysis [8]. No lead was in the propellant charge bags, so metals analyses were not required. Only residues outside the pan were sampled.

\section{Results}

Results are given for the energetics and metals in the residues within and surrounding the burn pan for the test of the original burn pan. The results for the modified burn pan are for energetic residues collected outside the burn pan only.

\subsection{Existing fixed burn pan location}

Results from the analyses of the $<2-\mathrm{mm}$ sieved sample fraction analyses for the three site characterizations of the soil surrounding the existing burn pan are given in Table 2. Estimated analyte surface concentration levels at the site rose over the years in the inner 8-m zone, where deposition from the inefficient disposal of propellants is greatest, indicating a buildup of contamination. In the outer zone, $>8 \mathrm{~m}$ from the pan, the concentrations do not vary much by year, indicating a persistence of the contaminants. Within the 0-4$\mathrm{m}$ sampling area we found high concentrations of both energetics (35 mg/kg 2,4-DNT, $6.4 \mathrm{mg} / \mathrm{kg} \mathrm{NG}$ ) and lead ( $5100 \mathrm{mg} / \mathrm{kg}$ ) as well as propellant grains on the ground that had been ejected during past

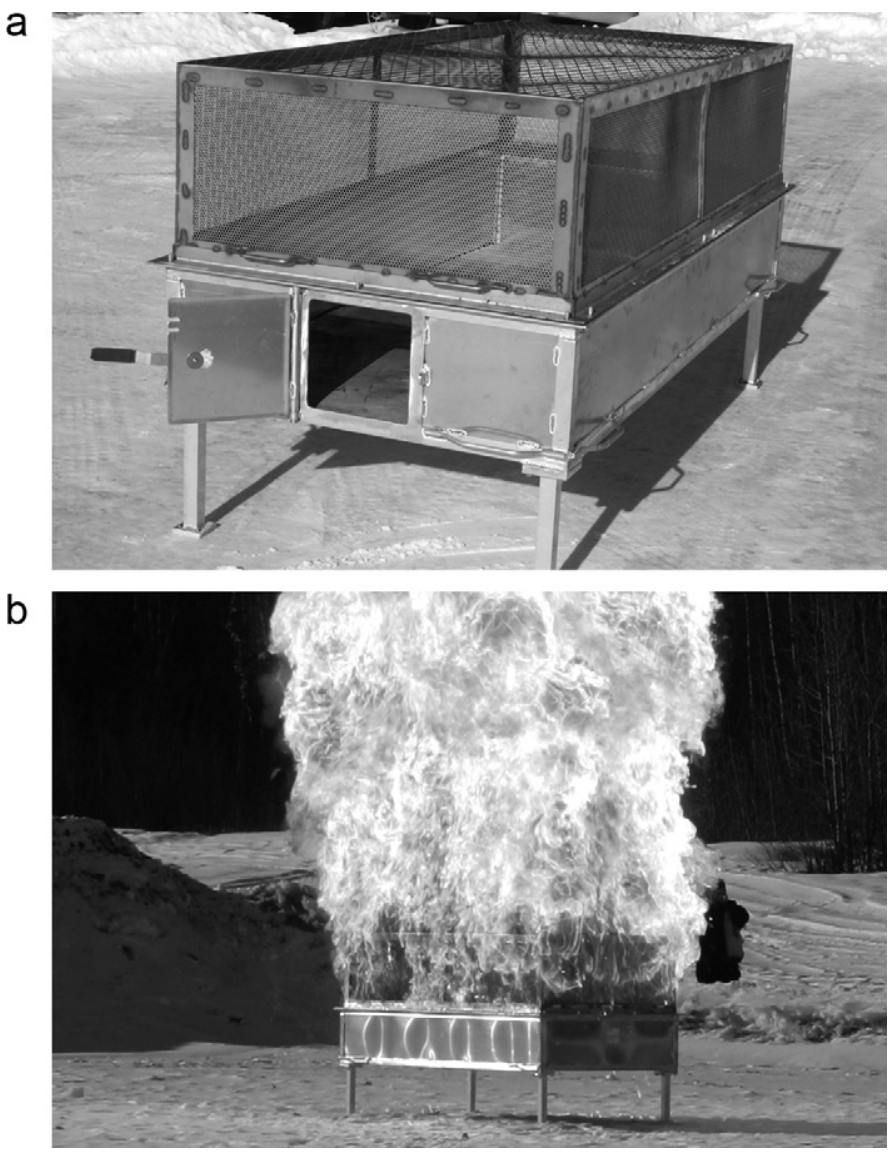

Fig. 2. Redesigned portable burn pan. (a) Prior to use. Access door is open. (b) In use burning $65 \mathrm{~kg}$ of M1 propellant charges. 
Table 2

Results of site characterization of an existing propellant burn pan location.

\begin{tabular}{|c|c|c|c|c|c|c|c|c|c|}
\hline Date & Replicates & Sampling unit ${ }^{\mathrm{a}}$ & $\operatorname{Mass}^{\mathrm{b}}(\mathrm{kg})$ & $\begin{array}{l}\text { Average no. of } \\
\text { increments }\end{array}$ & Statistic & $\begin{array}{l}2,4-D N T \\
(\mu \mathrm{g} / \mathrm{g})\end{array}$ & $N G(\mu g / g)$ & $\begin{array}{l}2,6-D N T \\
(\mu \mathrm{g} / \mathrm{g})\end{array}$ & $\begin{array}{l}\text { Lead } \\
(\mathrm{mg} / \mathrm{kg})\end{array}$ \\
\hline \multirow[t]{4}{*}{16 July 2003} & 6 & $<8 \mathrm{~m}$ & 2.8 & 36 & Mean & 8.2 & 2.8 & 0.20 & \\
\hline & & & & & Variance & 5.0 & 1.5 & 0.008 & \\
\hline & & & & & $R S D$ & $27 \%$ & $44 \%$ & $45 \%$ & \\
\hline & & & & & $95 \% U C L$ & 10 & 3.8 & 0.27 & \\
\hline \multirow[t]{4}{*}{25 September 2008} & 3 & $<8 \mathrm{~m}$ & 0.89 & 51 & Mean & 22 & 6.1 & 0.84 & \\
\hline & & & & & Variance & 14 & 15 & 0.032 & \\
\hline & & & & & $R S D$ & $17 \%$ & $63 \%$ & $21 \%$ & \\
\hline & & & & & $95 \% U C L$ & 28 & 13 & 1.1 & \\
\hline \multirow[t]{4}{*}{25 September 2008} & 3 & $8-10 \mathrm{~m}$ & 0.65 & 38 & Mean & 17 & 3.3 & 0.76 & \\
\hline & & & & & Variance & 33 & 0.043 & 0.10 & \\
\hline & & & & & $R S D$ & $33 \%$ & $6 \%$ & $42 \%$ & \\
\hline & & & & & $95 \% U C L$ & 27 & 3.7 & 1.3 & \\
\hline \multirow[t]{4}{*}{22 July 2009} & 3 & $<4 \mathrm{~m}$ & 0.45 & 18 & Mean & 35 & 6.4 & 1.7 & 5100 \\
\hline & & & & & Variance & 47 & 3.5 & 0.16 & \\
\hline & & & & & $R S D$ & $20 \%$ & $29 \%$ & $24 \%$ & \\
\hline & & & & & $95 \% U C L$ & 47 & 9.5 & 2.4 & \\
\hline \multirow[t]{4}{*}{22 July 2009} & 3 & $4-8 \mathrm{~m}$ & 0.47 & 19 & Mean & 16 & 3.4 & 0.51 & 860 \\
\hline & & & & & Variance & 56 & 0.14 & 0.08 & \\
\hline & & & & & $R S D$ & $45 \%$ & $11 \%$ & $55 \%$ & \\
\hline & & & & & $95 \% U C L$ & 29 & 4.0 & 0.98 & \\
\hline \multirow[t]{4}{*}{22 July 2009} & 3 & $8-10 \mathrm{~m}$ & 0.63 & 26 & Mean & 16 & 3.3 & 0.62 & 360 \\
\hline & & & & & Variance & 70 & 0.50 & 0.19 & \\
\hline & & & & & $R S D$ & $52 \%$ & $21 \%$ & $66 \%$ & \\
\hline & & & & & $95 \% U C L$ & 30 & 4.5 & 1.4 & \\
\hline
\end{tabular}

a Annulus radius from burn pan.

b Average mass of $<2-\mathrm{mm}$ sieved and ground samples.

burns. Propellant grains were found out as far as the $10-\mathrm{m}$ limit of the outermost sampling units.

\subsection{Prototype portable burn pan}

Tests were conducted on the METC Test range at DRDC Valcartier, Québec, QC, Canada, on 30-31 May 2010. Test material data is found in Table 1.

The propellant residues outside the pan were collected only for tests $1-3$ while the propellant residues inside the pan are from tests 1-4. A total of $5.85 \mathrm{~g}$ of non-metallic residues was recovered from the 10 trays that covered a combined area of $2.8 \mathrm{~m}^{2}$. There was an average of $0.32 \mathrm{~g}$ of DNT $(n=2)$ recovered from this mass. Extrapolated over the $20-\mathrm{m}^{2}$ area in which the sample trays were set, this results in an estimated $2.3 \mathrm{~g}$ of DNT ejected, representing $8.4 \times 10^{-3} \%$ of the original $27.6 \mathrm{~kg}$ of DNT in the initial three tests. The ash from within the pan was analyzed at CRREL. An estimated $0.83 \mathrm{~g}$ of DNT were contained in the $5.34 \mathrm{~kg}$ of ash $(n=3)$. This represents $2.1 \times 10^{-3} \%$ of the original $38.8 \mathrm{~kg}$ of DNT in all four tests. Extrapolating the ejected DNT over four tests and adding the DNT from the ash, we get $4.1 \mathrm{~g}$ of DNT residue, or $<0.011 \%$ of the original analyte load $(38.8 \mathrm{~kg})$. The reduction of the propellant mass is thus 99.99\%.

Following the removal of the ash from the pan at CRREL, the samples were examined for metals with a Niton XRF 700. The lead concentrations in the ash were significantly above the calibration range for the Niton $(10,000 \mathrm{ppm})$, so the data were meaningful only as an indication of very high concentrations of lead in the material.
Ten readings were taken of each size fraction following grinding. Results are given in Table 3.

Residues of lead in and outside the pan are for the two tests that included propellant bags that contained lead (tests 1 and 2). For the ejected material, a total of $46 \mathrm{~g}$ of lead was recovered from the trays, representing an estimated $320 \mathrm{~g}$ of lead in the $20-\mathrm{m}^{2}$ sample area. The mass of lead within the pan was estimated from the ICPMS analysis of the ground and subsampled ash. Table 4 depicts the average results of the analyses of the three size-fraction batches $(n=7)$. Multiplying the original size fraction mass by the analytical concentration results in an estimate of the mass contained in each size fraction. Summed, there is an estimated total of $740 \mathrm{~g}$ of $\mathrm{Pb}$ in the pan, found primarily in the smaller size fraction (61\%) with most of the remainder in the mid-sized fraction (37\%). The $740 \mathrm{~g}$ of lead in the ash, combined with the $320 \mathrm{~g}$ estimated to have been ejected into the $20-\mathrm{m}^{2}$ sampled area, represents $32 \%$ of the lead from the howitzer charges.

In addition to lead, the metals analyses results indicated that $1.1 \mathrm{~kg}$ of potassium was present in the ash. This represents $2.8 \mathrm{~kg}$ of $\mathrm{KNO}_{3}, 61 \%$ of the original $4.5 \mathrm{~kg}$ contained in the $40 \mathrm{M} 3 \mathrm{~A} 1$ charges. Subtracting out the $2.8 \mathrm{~kg}$ of $\mathrm{KNO}_{3}$ and $0.74 \mathrm{~kg}$ of Pb from the $5.34 \mathrm{~kg}$ of ash leaves $1.8 \mathrm{~kg}$ of material. The estimated DNT mass in the ash is $0.83 \mathrm{~g}$, which when multiplied by 10 gives a rough estimate of the M1 propellant remaining in the ash $(8.3 \mathrm{~g})$. The remainder of the ash, still around $1.8 \mathrm{~kg}$, is composed of other materials from the burning of the charges. This is around $0.4 \%$ of the original combined mass of the propellant charges, including all components (lead, bags, tags, flash suppressor, etc.).

Table 3

Niton XRF lead concentration readings ${ }^{\mathrm{a}}$ for the three ash size fractions from test at DRDC.

\begin{tabular}{|c|c|c|c|c|}
\hline Size fraction & Fraction mass (kg) & $\mathrm{Pb}$ concentration $(\mathrm{g} / \mathrm{kg})$ & Standard deviation & $\begin{array}{l}\text { Relative standard } \\
\text { deviation }\end{array}$ \\
\hline$>12.7 \mathrm{~mm}$ & 1.53 & 2.1 & 0.31 & 0.15 \\
\hline $12.7-2 \mathrm{~mm}$ & 1.93 & 13 & 1.9 & 0.15 \\
\hline$<2 \mathrm{~mm}$ & 1.88 & 32 & 9.2 & 0.29 \\
\hline
\end{tabular}

\footnotetext{
a Concentrations are above the calibration limit of the instrument.
} 
Table 4

Results of the metals analyses for lead in the size fraction samples of the ash.

\begin{tabular}{|c|c|c|c|c|c|c|}
\hline Size fraction & $\begin{array}{l}\text { Fraction } \\
\text { mass }(\mathrm{kg})\end{array}$ & $\begin{array}{l}\text { Pb concentration } \\
(\mathrm{g} / \mathrm{kg})\end{array}$ & $\begin{array}{l}\text { Standard deviation } \\
(n=7)\end{array}$ & $\begin{array}{l}\text { Relative standard } \\
\text { deviation }\end{array}$ & $\begin{array}{l}\text { Estimated mass } \mathrm{Pb} \\
\text { in fraction }(\mathrm{g})\end{array}$ & $\begin{array}{l}\text { Percent of total } \mathrm{Pb} \\
\text { in pan }\end{array}$ \\
\hline$>12.7 \mathrm{~mm}$ & 1.53 & 11 & 2 & 0.19 & 17 & $2 \%$ \\
\hline $12.7-2 \mathrm{~mm}$ & 1.93 & 140 & 51 & 0.37 & 270 & $37 \%$ \\
\hline$<2 \mathrm{~mm}$ & 1.88 & 240 & 28 & 0.12 & 450 & $61 \%$ \\
\hline
\end{tabular}

Temperatures for the first two tests are depicted in the graph in Fig. 3. Both tests utilized similar amounts of the same type of propellant, single-base M1 propellant, and the results are very similar. The much smaller quantity of single-base mortar propellant consumed in test $3,50 \mathrm{~kg}$, resulted in significantly lower maximum temperature of the pan, $87^{\circ} \mathrm{C}$ versus the $145^{\circ} \mathrm{C}$ of test $2(120 \mathrm{~kg}$ propellant). A thermocouple located $1 \mathrm{~m}$ from the end of the pan above the centerline of the screening of the bonnet during test 3 registered a maximum flame temperature of $483^{\circ} \mathrm{C}$, higher than the melting point of $\mathrm{Pb}\left(327^{\circ} \mathrm{C}\right)$. Radiant temperatures were measured $1.8 \mathrm{~m}$ from the side of the center of the burn pan and $2 \mathrm{~m}$ above the ground. Maximum temperature for the three tests on 30 MAR was $41^{\circ} \mathrm{C}$. Temperature data for test 4 were not collected. Burn times for the four tests are as follows: test 1, 19 s; burn 2, $21 \mathrm{~s}$; burn $3,11 \mathrm{~s}$; burn $4,17 \mathrm{~s}$.

\subsection{Redesigned burn pan}

The redesigned burn pan, incorporating the aluminum main pan and perforated stainless bonnet sides, was tested with a burn of $65 \mathrm{~kg}$ of M1 single-base propellant (Table 1). DNT was the analyte of interest. Propellant charges contained neither $\mathrm{Pb}$ nor $\mathrm{KNO}_{3}$. Results of the analyses indicate an estimated $1.6 \mathrm{~g}$ of the total DNT load was ejected during the burn. This is equivalent to approximately $16 \mathrm{~g}$ of propellant, which is $0.024 \%$ of the original propellant load. No warpage of the burn pan structure was observed following the test. The ash within the pan was not analyzed. Results for this and the previous tests conducted at DRDC are given in Table 5.

\section{Discussion}

The tests conducted for this study demonstrate significant results, but more work needs to be done to better define the effectiveness of the concept and perhaps develop a better, lighter design. The types and quantities of the propellants used in the tests

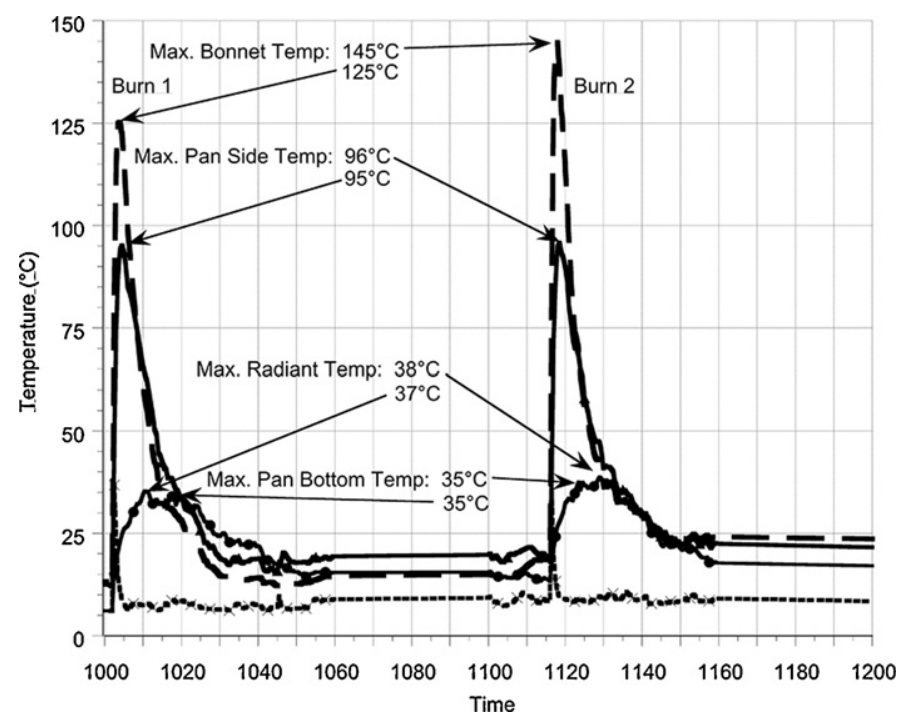

Fig. 3. Thermocouple responses to two burn events. conducted at DRDC are estimates. It is unknown how many pieces of lead foil were included in the propellant in tests 1 and 2 . We also did not make enough of an effort to account for all the lead, as we did not know that would be an issue at the time the first series of tests was run. The majority of lead in the ash on the bottom of the pan was found in the $<2-\mathrm{mm}$ fraction, indicating that the lead foil disaggregated into much smaller pieces. Lead was found on the grating at the top of the bonnet (Fig. 4a) and embedded in small particles of ash (Fig. 4b), indicating the lead may be becoming aerosolized. The nano-size particles in the ash fragments are of concern, as lead dust is quite toxic if inhaled and dissolution to groundwater is much more likely. Air emissions data collected by DRDC for burns in their fixed emplacement unit indicate only low levels of lead in the air [13], but this aspect of the disposal operation likely merits additional study. Preliminary results from 24 DRDC tests indicate up to $60 \%$ of $\mathrm{Pb}$ may be ejected from the burn tray under worst-case conditions (winter, high winds), with an average of $77 \%$ remaining in the tray [14]. Further study on this matter is required.

The majority of the byproduct of the disposal process, about $94 \%$, remained in the burn pan, $5.34 \mathrm{~kg}$ versus $0.32 \mathrm{~kg}$ recovered outside the pan. Collection and proper disposal of this material is greatly facilitated by the use of the pan. The pan was lightweight enough

a

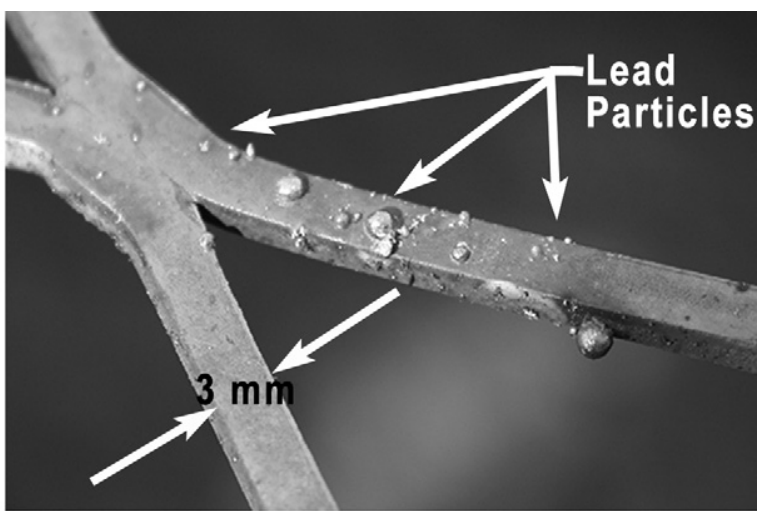

b

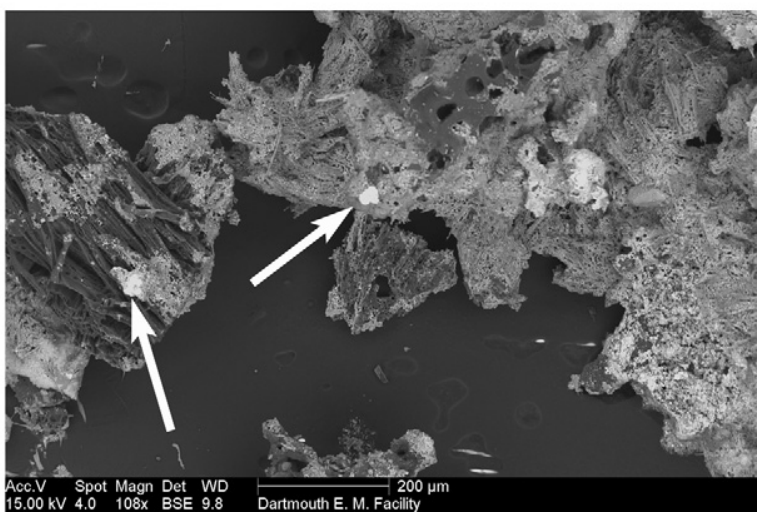

Fig. 4. Small particles of lead found following completion of burn tests in Canada. (a) Aerosolized lead precipitated out onto bonnet grating. (b) Lead particles (arrows) in an SEM image of post-burn ash. Courtesy: S. Taylor, USA CRREL. 
Table 5

Results of portable burn pan tests.

\begin{tabular}{|c|c|c|c|c|c|}
\hline Test Location & Reduction in propellant mass & DNT in pan $\left(\mathrm{g} / \%\right.$ total $\left.^{\mathrm{a}}\right)$ & DNT ejected ( $\mathrm{g} / \%$ total) & Lead in pan ( $\mathrm{g} / \%$ total) & Lead ejected ( $\mathrm{g} / \%$ total) \\
\hline DRDC & $99.99 \%$ & $0.83 / 0.0021 \%$ & $2.3 / 0.0084 \%$ & $740 / 22 \%$ & $320 / 9.7 \%$ \\
\hline Alaska & - & - & $1.6 / 0.024 \%$ & - & - \\
\hline
\end{tabular}

a \% total: Percent of total original mass: $38.8 \mathrm{~kg}$.

b Original DNT or lead in tests.

${ }^{\mathrm{c}}$ Estimate of energetic compound remaining after detonation.

${ }^{d}$ Percentage of original energetic compound in round remaining after detonation.

to be handled by three personnel, but a slightly lighter $(100 \mathrm{~kg})$ pan would be easier to maneuver.

Further design changes to the system have been made but not yet tested. The solid stainless steel false bottom has been changed to incorporate perforated stainless steel, both as the bottom and sides (16-cm high). The perforated material will lighten the unit's weight and allow better air and gas circulation, reducing the pressure of the burn. The sides will serve as a guide for the loading of the pan, limiting charge depth to the height of the sides. The access door to the pan is now part of the bonnet to facilitate initiation. A smaller unit has also been designed for smaller training activities that generate less excess propellants, such as small unit mortar training.

\section{Summary}

The burning of excess propellant in the field has the potential to be a significant source of energetics and heavy metal contamination on military ranges. The use of a portable burn pan has been shown to significantly reduce the residues and footprint of these expedient disposal actions [2]. These tests, combined with research done in Canada by DRDC, demonstrate that a well-designed burn structure can greatly reduce the concentrated environmental impacts these burns can have. The efficiencies of the propellant burns for the two tested portable pans were about $99 \%$, reducing hundreds of kilograms of propellant charges to a few $\mathrm{kg}$ of ash and debris. The burn pans designed and tested for this study have the potential to reduce energetic residues from the field expedient disposal of excess gun propellant by more than $99.9 \%$ through the more efficient burning of propellants in all weather conditions. The collection of post-burn residues for proper disposal is quick end easy as over $90 \%$ of the residues are contained within the pan. Lead is still a concern, as very small particles of lead are generated during the propellant deflagration process that aerosolized and may pose a significant human health risk through direct inhalation or groundwater contamination. Thus, the accumulation of fine lead particles around static burn pans could be a problem. Estimates for the containment of lead have proven problematic, as we have not been able to fully account for all the lead following the burns. Preliminary estimates range from around $15-40 \%$ ejection, based on the mass of lead recovered outside the pan. Overall, the environmental impacts of burning the excess propellants are greatly reduced when conducted in the portable burn pan. The armed forces of Canada are now required to dispose of all artillery propellants in static burn pans. We are working in the U.S. toward a similar change in policy, utilizing the portable burn pan to allow our soldiers to train as they fight, without an adverse environmental impact.

\section{Acknowledgements}

Funding for this project was granted by the U.S. Department of Defense Strategic Environmental Research and Development
Program (SERDP), Dr. Jeff Marqusee, Director, under the Environmental Restoration program, Dr. Andrea Leeson, Director. Research and development work was performed under project ER-1481: Characterization and fate of gun and rocket propellant residues on testing and training ranges, Mr. Michael R. Walsh and Dr. Sonia Thiboutot, principle investigators. The sponsor, SERDP, approved the research plan and provided funding. Study design; collection, analysis, and interpretation of the data; writing of the report; and all publication decisions were the sole responsibilities of the principle investigators.

\section{References}

[1] M.R. Walsh, M.E., Walsh, A.D. Hewitt, Energetic residues from expedient disposal of artillery propellants, ERDC/CRREL Technical Report TR-09-8, U.S. Army Engineer Research and Development Center-Cold Regions Research and Engineering Laboratory, Hanover, NH, 2009.

[2] M.R. Walsh, M.E. Walsh, A.D. Hewitt, Energetic residues from field disposal of gun propellants, J. Hazard. Mater. 173 (2010) 115-122.

[3] E. Diaz, S. Brochu, I. Poulin, D. Faucher, A. Marois, A. Gagnon, Residual dinitrotoluenes from open burning of gun propellant, in: Environmental Chemistry of Explosives and Propellant Compounds in Soils and Marine Systems: Distributed Source Characterization and Remedial Techniques, ACS Symposium Series, vol. 1069, American Chemical Society, New York, 2011, pp. 401-414.

[4] S. Jörgensen, M. Willems, The fate of lead in soils: the transformation of lead pellets in shooting range soils, Ambio 16 (1987) 11-15

[5] J. Clausen, J. Robb, D. Curry, N. Korte, A case study of contaminants on military ranges: Camp Edwards, Massachusetts, USA, Environ. Pollut. 129 (2009) $13-24$.

[6] Department of National Defence Canada, Ammunition and explosives procedural manual: Destruction of duds and misfired ammunition on CF ranges and training areas, Canadian Forces Procedural Manual C-09-008-002/FP-000, Department of National Defence, Office of the Deputy Chief of the Defence Staff, Ottawa, ON, 2005

[7] M.R. Walsh, S. Thiboutot, M.E. Walsh, G. Ampleman, R. Martel, I. Poulin, S. Taylor, Characterization and fate of gun and rocket propellant residues on testing and training ranges: Final report, ERDC/CRREL Technical Report TR-11-13, U.S. Army Engineer Research and Development Center-Cold Regions Research and Engineering Laboratory, Hanover, NH, 2011.

[8] USEPA, Nitroaromatics and nitramines by HPLC, USEPA SW-846 Method 8330B, U.S. Department of Environmental Protection, Washington, DC, 2006.

[9] USEPA, Inductively coupled plasma-mass spectrometry, USEPA SW-846 Method 6020A, U.S. Department of Environmental Protection, Washington, DC (2007).

[10] USEPA, Microwave assisted acid digestion of sediments, sludges, soils, and oils, USEPA SW-846 Method 3150A, U.S. Department of Environmental Protection, Washington, DC, 2007

[11] T.F. Jenkins, M.E. Walsh, P.H. Miyares, A.D. Hewitt, N.H. Collins, T.A. Ranney, Use of snow-covered ranges to estimate the explosives residues from high-order detonations of army munitions, Thermochim. Acta 384 (2002) 173-185.

[12] M.R. Walsh, M.E. Walsh, C.A. Ramsey, Measuring energetic residues on snow ERDC/CRREL Technical Report TR-07-19, U.S. Army Engineer Research and Development Center-Cold Regions Research and Engineering Laboratory, Hanover, NH, 2007.

[13] S. Thiboutot, G. Ampleman, M.R. Walsh, M. Kervarec, A. Gagnon, A. Marois, F. Boucher, Development of burn trays for the disposal of propellants, In: A.S Cumming and J. Hagvall (Eds.), Munition and Propellant Disposal and its Impact on the Environment, Edinburgh, Scotland. North Atlantic Treaty Organization, Research and Technology Organisation, Neuilly-sur-Seine, France. RTO Meeting Proceedings MP-AVT-177, 2011, pp. 20-1-20-22.

[14] S. Thiboutot, G. Ampleman, M. Kervarec, A. Gagnon, A. Marois, D. Pantea, S. Withwell, Determination of lead mass balance during open burning of artillery propellants, in: Proceedings of SERDP/ESTCP 2011 Workshop and Symposium, Washington, DC, November 2011. 